\title{
Open Innovation Strategies and Appropriability in Knowledge-Intensive Business Services: Evidences and Implications in the Brazilian Context
}

\author{
Eurico Sprakel ${ }^{1}$ \\ sprakel@uol.com.br|@0000-0001-6751-141X \\ Andre Machado ${ }^{1}$ \\ agcmachado@gmail.com| $\mid$ 00000-0002-0589-896X
}

\section{ABSTRACT}

This paper analyzes open innovation strategies and their implications on appropriability and performance in Knowledge-Intensive Business Services (KIBS) firms which operate in the Brazilian market. This is cross-sectional research relying on the survey method. Data was collected through a questionnaire applied to 345 firms that provide Information Technology (IT) and Business Management Consulting services. Cluster analysis was the main technique employed for data analysis. The results showed that KIBS firms, whose inbound and outbound flows difference is small, eventually use appropriation mechanisms to a greater extent and adopt the selective revealing strategy more intensely. It is concluded that Brazilian KIBS firms adopt inbound knowledge flows more intensely, and that firms herein labelled as "neutral" presented greater appropriation and innovation performance than "externalizing", "internalizing" or "very internalizing" firms.

\section{KEYWORDS}

appropriability, selective revealing, open innovation, innovation performance, KIBS 


\section{INTRODUCTION}

As technology becomes more complex and firms look for solutions to reduce costs, risks, and the time required for innovation development, businesses are more and more interested in using open innovation strategies (Lazzarotti, Bengtsson, Manzini, Pellegrini, \& Rippa, 2017). Openness strategies, typical of firms that provide Knowledge-Intensive Business Services (KIBS), heighten concerns with knowledge protection due to the need to guarantee knowledge sharing and revealing.

Openness implies externalizing knowledge, which may lead to leakages in the collaboration process, and conflicts over determining the ownership of knowledge developed jointly with clients (Miozzo, Desyllas, Lee, \& Miles, 2016). On the other hand, excessive emphasis on protecting knowledge (Laursen \& Salter, 2014; Arora, Athreye, \& Huang, 2016) may generate relationship issues and external collaboration problems, since there is a risk of prioritizing control to the detriment of knowledge trading.

As Teece (1986) alludes to, the expected benefits for a firm that develops innovation depend not only on a successful innovation process but also on such firm's capacity to "appropriate" the benefits so as to protect knowledge and innovations from imitation by competitors. Thus, the organizations' capacity to secure the gain from innovation activities as they delay, stop, or protect themselves from the action of imitators is understood in this paper as appropriability, and it takes on a relevant role for open innovation purposes.

Although knowledge appropriation may occur both through formal mechanisms (Laursen \& Salter, 2014; Arora et al., 2016) and informal mechanisms (Baldwin \& Henkel, 2015; Freel \& Robson, 2017; Zobel, Lokshin, \& Hagedoorn, 2017), a firm may also adopt the strategy of deliberately renouncing knowledge through selective revealing. In such case, the firm purposely waives intellectual property rights by selectively revealing some knowledge (Henkel, 2006) to induce other actors to co-create technologies adopted by the firm.

Although some studies show the relation between appropriation mechanisms and the degree of openness (Laursen \& Salter, 2014; Arora et al., 2016), researches still need to further explore the patterns that relate appropriability strategies and openness strategies (Laursen \& Salter, 2014), as well as patterns that explain such behavior in KIBS (Arora et al., 2016). In addition, most of the quantitative studies on openness (degree of open innovation practices adopted) rely on databases of innovation researches conducted by national statistics offices, upon instructions of the Community Innovation Survey (CIS), that is, a secondary database.

There is a need for studies that assess the influence of several openness modes on innovation performance (Van de Vrande, Vanhaverbeke, \& Duysters, 2009; Cheng \& Huizingh, 2014; Bengtsson et al., 2015). The potential impacts of such studies are connected to the generation of new ideas (Teirlinck \& Spithoven, 2013), variety of channels and heterogeneous knowledge (West \& Bogers, 2014). Excessive openness, for example, leads to information overload since many simultaneous partnerships generate difficulties for detecting knowledge that is highly important and complementary, as well as for absorptive capacity (Cohen \& Levinthal, 1990; Nooteboom, 1999; Katila \& Ahuja, 2002; Barge-Gil, 2010).

All this considered, our research problem may be presented as follows: what are the implications of open innovation strategies on appropriability and innovation performance in KIBS firms in Brazil? Therefore, the objective of this paper is to analyze open innovation strategies and their implications on appropriability and innovation performance in KIBS firms operating in the Brazilian market. 
This work's outcomes contribute to understanding the open innovation strategies (inbound, outbound and coupled) used in Brazilian KIBS firms. In addition, it introduces the concept of "selective revealing", which is still scarcely explored in the literature but which constitutes an important factor to understand the relation between openness and appropriability. This study also advances the creation of categories, (internalizing, neutral and externalizing), based on how intensely inbound and outbound flows are used, which contribute to comprehending open innovation strategies and their influence on innovation performance, appropriability, and selective revealing.

After this introductory section, the theoretical background discusses the following themes: knowledge-intensive business services; open innovation; appropriability; selective revealing; and, innovation performance. After that, we present the methodological procedures, encompassing general characteristics of this study; population; sample; data collecting procedure; research variables; and, data analyses techniques. In the fourth section, we present data analyses and discussions. Finally, the paper is concluded by reporting its contributions, limitations, and suggestions for further research.

\section{THEORETICAL BACKGROUND}

\subsection{Knowledge-InTEnsive Business SerVices}

KIBS firms are innovation co-producers with clients because they are hired by other firms to leverage their knowledge in one specific area. This type of firm is usually engaged in searching for some specific solution and eventually works as a complementary, or even main, provider of the client's innovation solution (Love, Roper \& Bryson, 2011).

In general terms, the activities conducted by KIBS firms are more complex than those in other service sectors, and the degrees of innovation are higher than in some manufacturing sectors (Djellal, Gallouj \& Miles, 2013). Besides, KIBS firms use external knowledge to a greater extent (Mina, Bascavusoglu-Moreau \& Hughes, 2014), that is, they are likely more open. KIBS provide intensive knowledge input for other firms' business processes (Shi, Wu \& Zhao, 2014) such as, for example, advertising services, information technology, management consulting, among others.

The activities conducted by KIBS firms are very heterogeneous (Rodriguez \& Camacho, 2008), however, Strambach (2008) underscores they have three features in common: (i) knowledge is not only a key production factor of the firms, it is also the good they sell; (ii) there is in-depth interaction between supplier (KIBS) and user (firms), and both parties are involved in cumulative learning processes; (iii) service providing is connected with clients' needs to a great extent.

The activities that KIBS firms undertake may be classified differently, according to their country of origin. In Brazil, the reference is the National Classification of Economic Activities (Classificação Nacional de Atividades Econômicas - CNAE) whereas in Europe it is determined by the Nomenclature of Economic Activities (NACE). However, since the United Nations (UN) promotes an international standardization for classifying economic activities in member countries and signatories, the NACE and CNAE are equivalent in the level of division (2 digits) of the economic activities.

KIBS can also be divided into two large groups, separated by the innovation patterns: technologybased firms (t-KIBS), such as information technology services, engineering and R\&D consulting, and professional KIBS (p-KIBS), such as management, accounting, and market research (Strambach, 2008; Corrocher, Cusmano \& Morrison, 2009). These two groups may adopt different innovation strategies, such as those found in the work of Rodriguez, Doloreux and Shearmur (2016). 


\subsection{Open INNOVATION}

Open innovation is "a paradigm that assumes that firms can and should use external ideas as well as internal ideas, and internal and external paths to market, as the firms look to advance their technology." (Chesbrough, 2003, p. XXIV). One important idea incorporated in this concept regards the intentional management of inbound and outbound knowledge flows, which serve to accelerate internal innovation and expand external markets (Chesbrough, 2006).

Openness is associated with the intensity of the inbound and outbound knowledge flows and the different forms of relationships with external actors (Dahlander \& Gann, 2010). The degree of openness is defined as the amount of, and intensity of, use of external sources (clients, suppliers, competitors, universities, research centers etc.) throughout the innovation process (Laursen \& Salter, 2006; Leiponen \& Helfat, 2010).

Both "breadth" and "depth" (Laursen \& Salter, 2006) are dimensions used to measure the degree of openness (Drechsler \& Natter, 2012; Idrissia, Amaraa, \& Landrya, 2012; Lazzarotti et al., 2017). Breadth is defined as the number of external sources, or search channels, that firms rely upon in their innovation activities. Depth, in turn, concerns the intensity of the collaboration between a focal firm and each of said sources.

Intensity depends on a specific firm's needs to keep solid and frequent contact with the knowledge source. This openness dimension may lead to a greater confidence in the relations with external actors, thus reducing the risks of opportunistic behaviors, and generate a lesser need to use protection mechanisms.

Breadth is associated with the number of relationships with heterogeneous actors, which implies the access to a greater knowledge variety (for example, Nooteboom, 1999; Katila \& Ahuja, 2002). The access to knowledge diversity may also occur due to the number of partnerships with one single category of external actors (for example, a number of collaborative partnerships with clients and suppliers), although it generates lesser access to heterogeneous knowledge.

Involving many partners creates opportunities to explore different knowledge sources that may contribute to innovation but may generate greater difficulty to integrate knowledge, and raise costs due to the need to manage a greater number of transactions (Katila \& Ahuja, 2002; Laursen \& Salter, 2006). When the breadth of openness is excessive, it may discourage potential partners to engage in relationships because they will not invest in transactions unless they are sure they will be selected as partners. Thus, some firms prefer to participate in a small number of relationships with a higher level of confidence and durability.

Apart from the dimensions proposed by Laursen and Salter (2006), openness may be analyzed from the following perspectives (Gassman \& Enkel, 2004, Huizingh, 2011): (a) inbound, that is, the internal use of external knowledge; (b) outbound, that is, sending knowledge to the external environment; (c) coupled, a combination of the two processes above, forming alliances with complementary partners.

The inbound flows serve to update and complement the existing knowledge in the firm. Acquisition and access to external knowledge are associated with detecting complementary and valuable knowledge (Natalicchio, Ardito, Savino, \& Albino, 2017) and absorptive capability (Cohen \& Levinthal, 1990). Another important issue, regarding the inbound process, is the Not Invented Here Syndrome (NIH), in which employees have a negative attitude towards the 
acquisition of external knowledge. They consider the knowledge of the firm where they work to be superior to that of other firms, and believe that external technologies have nothing to add (Gassmann \& Enkel, 2004; West \& Bogers, 2014). The opposite end of this syndrome would be an exaggeratedly positive view of knowledge acquisition, as if it would solve all the problems of the firm, thus overestimating acquired or accessed knowledge (Natalicchio et al., 2017).

The degree of inbound openness regards the effective access to tacit knowledge. If the knowledge to be taken in is far beyond a firm's capacity of development, perhaps purchasing technologies is the most suitable strategy. The access to external knowledge may be obtained by means of intermediators, such as crowdsourcing platforms ("outsourcing as allocating a task in the problem solving process”) (Brunswicker \& Van De Vrande, 2014, p. 175), which focus on external actors that many times are not clients nor suppliers, but rather, are individuals motivated by some financial benefit or professional recognition.

In addition to crowdsourcing, inbound flow is also associated with buying patents and copyright licenses (licensing-in) (Ahn, Minshall, \& Mortara, 2015). Another form of inbound knowledge flow is participation in venture capital firms (venturing-in), generally by startups in the technology sector, which are funded by bigger organizations to provide some specific knowledge.

Outbound knowledge flows, however, occur when a firm sees that the revenues of revealing and selling are greater that the losses due to spillover. Outbound openness must be well analyzed for essential knowledge to be maintained, in a way that the firm will not lose its competitive advantage. Some examples of outbound process are licensing-out, spining-off, and open-sourcing strategies (Ahn, Minshall, \& Mortara, 2015).

Firms that do openness by means of outbound flows may face the Only Used Here (OUH) Syndrome, in which the firm will not sell the knowledge produced within to avoid losing the potential return (Lichtenthaler \& Ernst, 2006). This issue is closely associated with the way a firm handles the protection mechanisms and how easy knowledge spillover is expected to occur in its field of activity.

The Sell-out strategy goes quite the opposite way, in which a firm takes an extremely positive attitude towards purchasing external knowledge (Lichtenthaler \& Ernst, 2006) and undervalues the possible negative consequences of such operation. This lack of understanding usually occurs due to information asymmetry, which may lead to wrong knowledge-protecting strategies.

In contrast, firms that exert technological leadership are more likely to benefit from the use of outbound processes, by licensing out and selling their intellectual property (copyright licensing or patenting) (Idrissia et al., 2012). On the other hand, less advanced firms face more difficulties to generate revenue from patenting and licensing out and, potentially, gain more from collaborations.

The coupled process, in turn, involves cooperation relations between actors, and considers simultaneous inbound and outbound knowledge flows (Enkel, Gassmann, \& Chesbrough, 2009). In the coupled processes, the firm must be able to access and retain knowledge because, for collaboration to be long-lasting, inbound and outbound knowledge flows must be reciprocal, since there is no interest in keeping cooperation if the firm turns over its knowledge and cannot absorb knowledge that complements its own. 


\subsection{Appropriability, Selective reVEaling and InNovation PERFormanCe}

An essential condition for a firm to obtain positive results from innovation development is the capacity to prevent or delay unwanted duplication of its intellectual assets and technologies (Hurmelinna-Laukkanen, Sainio, \& Jauhiainen, 2008). If firms have the chance to copy or explore their competitors' knowledge at a low (or no) cost, competitive advantage is lost and obtaining returns from investments in innovation becomes unfeasible.

Such concern with protecting and capturing the value of knowledge-based assets is even bigger when firms are dealing with external actors in search of innovations. The existing literature intricately uses terms such as protection mechanisms, appropriation, appropriability, appropriability regime, among others.

The term appropriation has a broader connotation than protection. Appropriation implies the idea of protection and, subsequently, capturing knowledge value, that is, the return on knowledge and innovation assets. Appropriability regime concerns the strategies used by the firm to this end. Appropriability is the capacity of organizations to appropriate the gains from innovation activities; therefore, it is the likelihood of delaying or preventing the action of imitators (Miozzo et al., 2016). In addition to protecting innovation, the correct appropriability strategies hamper the action of competitors in some fields of knowledge.

Appropriability mechanisms concern strategic control of knowledge, technologies and information, allowing firms to enjoy and benefit from some innovation, by delaying or preventing competitors from creating imitations (Hurmelinna-Laukkanen et al., 2008). Knowledge appropriation mechanisms are divided into formal and informal (Hall, Helmers, Rogers, \& Sena, 2014; Freel \& Robson, 2017). Contracts and confidentiality agreements, also called nondisclosure agreements, may be considered semi-formal mechanisms (Arora et al., 2016) but they were not covered in this study.

The use of informal mechanisms may be more common in firms in the service sector (Leiponen \& Byma, 2009). This is due to the difficulty of proving the authorship of service innovations (which may be explained by causal ambiguity) and, consequently, of filing legal suits in case of imitation (Freel \& Robson, 2017).

When knowledge embedded in innovation has many coded elements, firms prefer to protect it through patenting. However, when the tacit element is stronger, the difficultly of transfer of knowledge is greater and firms prefer to keep it a secret and/or rely on the difficulty of imitation due to its complexity.

In addition, more empirical experience-based knowledge, as for example, consultancy done by KIBS firms in the field of organizational management are hard to protect through formal mechanisms. Such knowledge is more difficult to codify because the firm would have to detail numerous existing relationships. In turn, sectors in which technology is easily codified (such as pharmaceuticals) use formal mechanisms (patenting) to a great extent.

A firm may also adopt selective revealing practices, which may be defined as "the voluntary, purposeful, and irrevocable disclosure of specifically selected resources, usually knowledge-based, that the firm could have otherwise kept proprietary so that it becomes available to a large share or even all of the general public, including the competition of the firm" (Alexy, George, \& Salter, 2013, p. 272).

Selective revealing is said to be a collaboration strategy in which the focal firm "reveals" knowledge and waives intellectual property rights (for example, patenting or copyright) to the external community (Henkel, 2006). The decisions to reveal or keep their knowledge to themselves 
depends on the interests towards each external actor and on defining which parts (modules) of knowledge will be disclosed and which will be retained.

Finally, measuring performance in innovation may include a series of factors, such as innovations of products and services introduced by the firm, participation in sales of new products and services, and the frequency that innovations are introduced when compared to competitors (Aloini et al., 2015). In general terms, measuring occurs by means such as: number of patents filed in a specific period (Arora et al., 2016; D’Ambrosio, Gabriele, Schiavone, \& Villasalero, 2017), number of new products (Cui et al., 2015), percentage of products/processes (goods or services) that are new to the firm, to the market and to the world (Laursen \& Salter, 2006).

Some studies, such as those of Martini et al. (2012), Aloini et al. $(2015 ; 2017)$ and D'Ambrosio et al. (2017) use latent scales to measure innovation performance. This alternative seems rather valid given the difficulty of quantifying the "percentage" of new products, or using patents as an indicator of innovation performance in the service sector.

\section{METHODOLOGICAL PROCEDURES}

This is a cross-sectional study; it uses the survey method (Babbie, 2003) and aims to capture the studied phenomenon within a short period of time (over the last 12 months). The survey and data analysis are done through a quantitative process, in which the phenomena are measured, and analyses is then conducted on the statistical treatment of the data.

The number of existing firms in Brazil that suit KIBS-related CNAEs can be found at the Annual List of Social Information database (Relação Anual de Informaçóes Sociais - RAIS), of the Brazilian Ministry of Labor (Ministério do Trabalho). By analyzing the number of firms whose CNAEs are associated with KIBS, we chose activities that adhere more to the use of appropriation strategies and open innovation. This way, we chose to select a sector to represent t-KIBS, namely information technology services (CNAE 62.0), and another for p-KIBS, namely business management consulting activities (CNAE 70.2).

From this perspective, in 2017, the latest year of data published by RAIS before we collected the data, there were 26,431 firms providing Information Technology services and Business Management Consulting. For such a universe, at 95\% confidence level, 6\% error, we need a sample of 265 firms (Hair et al., 2009). The sample used in the study had 345 respondent firms. This was a non-probabilistic sample, to suit our conveniences, in which we chose the population members based on their accessibility and availability for filling out the questionnaire.

Data was collected by means of a structured questionnaire (instrument of data collection) applied from August to October 2018, which allowed us to form latent constructs (see Appendix A). We collected 345 questionnaires, applied to Information Technology Service firms (247 respondents) and Business management consulting (98 respondents), labelled in this study as t-KIBS and p-KIBS, respectively. Data was collected online through Survey Monkey, which allows designing and sending out questionnaires.

To understand KIBS firms' behavior regarding open innovation strategies (breadth and depth) we conducted a cluster analysis. This technique aims to group respondents (firms) on their characteristics. Each respondent is clustered according to the characteristics chosen by the researcher. Clustering is done as a function of homogeneity and heterogeneity (distance) from the set of input variables (Hair, Black, Babin, Anderson, \& Tatham, 2009). By applying cluster analysis, we may detect features that are similar to groups of firms and check the outcomes of the variables picked in the study for each of the chosen groups. 
In this study, we used the non-hierarchical clustering method, in which the user previously decides on the number of clusters $(\mathrm{k})$ to be segmented. However, this previous determination may result in the formation of clusters that are not very representative. Therefore, several values of $\mathrm{k}$ were tested. The non-hierarchical method used was k-means, which basically consists of placing individuals (firms) in the group in which the centroid is nearest (nearest centroid sorting) (Hair et al., 2009). The measurement used to identify the degree of similarity was the Euclidian distance.

The research was modeled on four major constructs: appropriation mechanisms, selective revealing, openness and innovation performance. The items that compose each construct were selected based on a review of literature; next, face and content validity were verifired. All questionnaire items were measured on a seven-point Likert scale (1 to 7), with anchor terms at both ends.

The degree of openness for the inbound, outbound, and coupled flows was calculated by means of relations with external actors (as laid out in the construct "Openness" in Appendix A) and the focal firm (Laursen \& Salter, 2006, 2014; ALOINI et al., 2015; Greco, Grimaldi, \& Cricelli, 2016; Freel \& Robson, 2017). Breadth and depth were calculated indirectly on the relationship intensity $(r i)$ that firm $(\mathrm{k})$ assigned to each external actor (i), ranging from 1 to 7 (Likert Scale) regarding the inbound, outbound and coupled flows. For breadth, each external actor (i) type is codified as a binary variable, in which 0 indicates no relations with the focal firm whereas 1 indicates a relationship.

If eleven actors are listed on the questionnaire, the breadth of openness for each firm $\mathrm{k}$ may range from 0 to 11; zero in case of no expressive relationship with an external actor and 11 in case of expressive relationship with all the external actors listed.

$$
\text { Breadth }_{k}=\sum_{i=1}^{11} \text { breadth }_{i k}
$$

Where breadth ${ }_{\mathrm{ik}}=\{1$ if $\mathrm{i}$-th external source has been relationship intensity $r i \geq 3$; otherwise, 0$\}$

The breadth of openness indicates the number of external actors with which the firm is open to trading knowledge and innovation with. In this study, we chose to consider that a firm has no external relation with another actor if the answer was [1 and 2] in the scale. As to the remaining values [3 to 7] we considered them an expressive relationship with the external actor. For each external actor, if the relationship intensity is $\geq 3$ on a 1 to 7 scale, we consider there is a relationship, otherwise, we attribute a 0 value and the external actor is not added for counting breadth.

Depth is the frequency with which a KIBS firm associates with an external actor. On this parameter, we consider that the mean value for relationship intensity ( $r i$ ) with the 11 actors listed (i) on the questionnaires for each of the openness flows. Thus, the depth value for each firm $\mathrm{k}$ may range from 1 to 7 . 
The breadth of openness for each firm $\mathrm{k}$ ranges from $[0,11]$, while depth may range from $[1,7]$. For a comparable basis, both results become parameters on a scale $[0,100]$.

$$
\begin{aligned}
& \text { Breadth }_{k[0,100]}=\frac{\text { Breadth }_{k}}{11} \times 100 \\
& \text { Depth }_{k[0,100]}=\frac{\text { Depth }_{k}-1}{(7-1)} \times 100
\end{aligned}
$$

Throughout the work, breadth and depth were used to represent openness, for example "inbound breadth" or "inbound depth". We also used (total) breadth and (total) depth, which were weighted on the factor charges of the three flows (inbound, coupled and outbound).

We used the R software "mclust" package for the cluster analysis. To obtain the descriptive statistics, (Pearson) correlations and (Wilcoxon) Hypothesis Test, we also used R. The Wilcoxon Test was used to evaluate if there was a significant difference between the sample averages of the $\mathrm{t}-\mathrm{KIBS}$ and $\mathrm{p}-\mathrm{KIBS}$ groups.

\section{RESULTS AND DISCUSSIONS}

As shown in the methodological procedures section above, the values of breadth and depth of openness were transformed into a 0-100 scale to facilitate reading comprehension as well as the quantitative instrumentation (explained in the methodological procedures). Appropriation, selective revealing and innovation performance, in turn, are represented by measures ranging from 1 to 7, according to the Likert Scale used in the instrument of data collection.

The (exploratory) factor analysis results for each latent construct used are displayed in Appendix B. Table 1 shows the measures of central tendency values (mean and median) and dispersion (standard deviation) for the four major constructs of this study. In addition, it shows the statistics for formal and informal appropriation and for the several types of openness.

The Wilcoxon Test evidenced no significant differences ( $\mathrm{p}$-value $<0.05$ ) between the means of the t-KIBS and p-KIBS constructs.

From the results displayed in Table 1, formal appropriation strategies are much less used than informal appropriation strategies. The inbound relation is more intense and broader than outbound and coupled relations. In this case, it is believed that inbound knowledge flow will be greater than outbound flow in KIBS firms, that is, there will be more internalization than externalization. 
Table 1

Descriptive indicators for the studied dimensions

\begin{tabular}{lccccccc}
\hline & Mean & Median & S.D & Minimum & Maximum & Asymmetry & Kurtosis (K) \\
\hline Formal Appropriation & 3.04 & 2.75 & 1.71 & 1 & 7 & 0.46 & -0.83 \\
Informal Appropriation & 4.89 & 5.20 & 1.18 & 1 & 7 & -0.72 & 0.37 \\
\hline Appropriability & 4.06 & 4.00 & 1.19 & 1 & 6.67 & -0.07 & -0.49 \\
Selective Revealing & 3.52 & 3.50 & 1.61 & 1 & 7 & 0.08 & -0.89 \\
Innovation performance & 5.02 & 5.20 & 1.28 & 1 & 7 & -0.61 & 0.30 \\
Openness & 48.13 & 47.59 & 25.73 & 0 & 98.30 & 0.06 & -0.95 \\
\hline Inbound Breadth & 63.32 & 63.64 & 28.25 & 0 & 100.00 & -0.43 & -0.72 \\
Inbound Depth & 42.76 & 42.42 & 20.51 & 0 & 100.00 & 0.15 & -0.31 \\
Outbound Breadth & 50.62 & 45.45 & 31.23 & 0 & 100.00 & 0.21 & -1.14 \\
Outbound Depth & 27.17 & 22.22 & 24.62 & 0 & 100.00 & 0.85 & 0.06 \\
Coupled Breadth & 51.70 & 45.45 & 32.13 & 0 & 100.00 & 0.15 & -1.20 \\
Coupled Depth & 27.47 & 19.44 & 26.29 & 0 & 100.00 & 0.88 & -0.08 \\
\hline
\end{tabular}

Source: Research data (2018).

Studies, such as those by Enkel et al. (2009) and Ahn et al. (2016) also found that inbound practices are more frequent than outbound practices. In Brazil, this seems coherent since there are many barriers for licensing knowledge in the form of copyright (or patenting). In addition, it is believed that the corporate perspective on appropriation still needs to evolve so that patterns may change.

The lesser frequency of outbound flows use is also associated with the view that appropriation is connected with negative right, that is, it regards guarantees of non-interference of one firm on the rights of another firm. Appropriation strategies are also connected with the intention of preventing overspilling (Chesbrough \& Ghafele, 2014) rather than being interpreted as a sponsor of licensing.

Table 2 shows the (Pearson) correlations between constructs (items' means). There is a strong correlation between breadth and depth (0.89) and a strong relation between selective revealing and the two openness dimensions (breadth and depth). All the correlations are significant for p-value $<0.001$, at (Student's) t-test.

Table 2

Correlations between the main constructs

\begin{tabular}{lcccccc}
\hline & $\begin{array}{c}\text { Formal } \\
\text { Appropriation }\end{array}$ & $\begin{array}{c}\text { Informal } \\
\text { Appropriation }\end{array}$ & $\begin{array}{c}\text { Selective } \\
\text { Revealing }\end{array}$ & $\begin{array}{c}\text { Innovation } \\
\text { performance }\end{array}$ & Breadth & Depth \\
\hline Formal Appropriation & 1.00 & - & - & - & - & - \\
Informal Appropriation & 0.41 & 1.00 & - & - & - & - \\
Selective Revealing & 0.37 & 0.31 & 1.00 & - & - & - \\
Innovation performance & 0.29 & 0.48 & 0.29 & 1.00 & - & - \\
Breadth & 0.41 & 0.37 & 0.56 & 0.29 & 1.00 & - \\
Depth & 0.44 & 0.35 & 0.56 & 0.30 & 0.89 & 1.00 \\
\hline
\end{tabular}

Note: For all correlations p-value $<0.001$ (t-Test)

Source: Research data (2018). 
BBR

18

72

The inbound, outbound and coupled knowledge flows strongly correlated with each other. This seems to be very coherent since the "organizational culture of openness" represents a trend of several types of transactions (access, revealing, purchasing, sales and cooperation) with external actors (Cheng \& Huizingh, 2014; Cassiman \& Valentini, 2016).

This outcome corroborates the findings of Cassiman and Valentini (2016), which evidenced that inbound and outbound flow activities are complementary. For them, when a firm adopts inbound and outbound strategies simultaneously, the result is innovation performance improvement. Cheng and Huizingh (2014) also measured the relation among the three flows (inbound, outbound and coupled) and identified that they all correlated significantly with each other.

Cluster analysis consisted of constructing two new variables on the difference between flows (inbound - outbound) for breadth and depth. Such two variables were used as inbound features for the non-hierarchical clustering (k-means) of the KIBS firms. This "balance" serves to verify whether KIBS firms that eminently "internalize" or "externalize" knowledge behave differently.

To analyze the number of clusters, a dendrogram (also called tree diagram) is generally used, where each branch represents an element. By using a dendrogram we may have previous knowledge of how data is structured and, thus, facilitate the subjective decision of how many groups must be formed. Figure 1 presents the dendrogram and the Elbow Chart to determine the number of clusters.

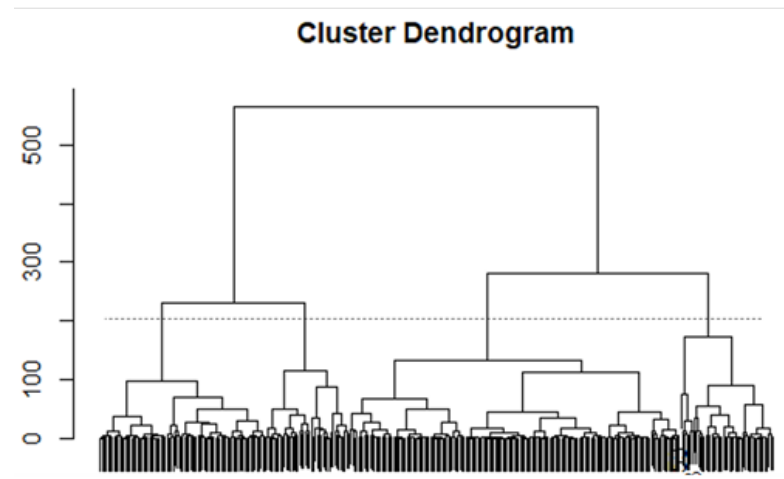

Figure 1. Dendrogram and Elbow Chart. Source: Research data (2018).

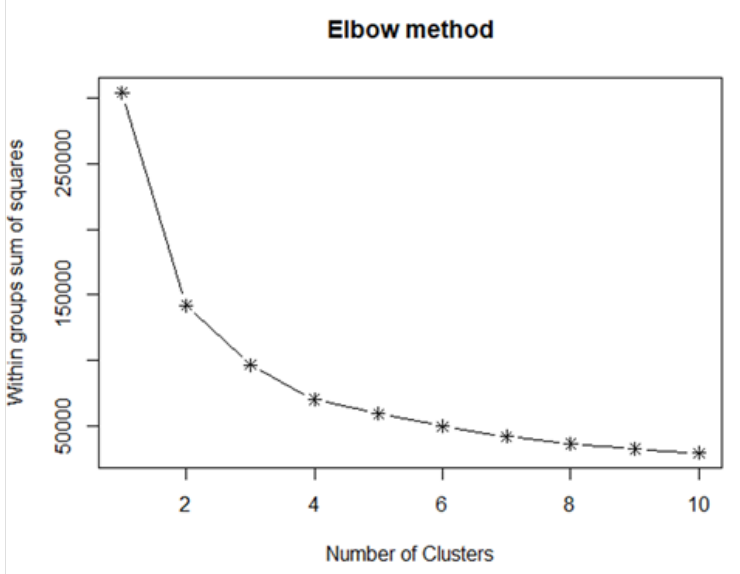

The visual analysis of the Elbow Chart and dendrogram shows that forming four clusters seems the most evident, although we also performed tests with other numbers. Figure 2 shows the graphic results for the clusters on the $\mathrm{k}$-means technique forming four clusters. These groups were named, in this work, as "externalizing", "neutral", "internalizing" and "very internalizing" firms. The centroid results show the subtraction of inbound and outbound flows in the breadth and depth dimensions. 


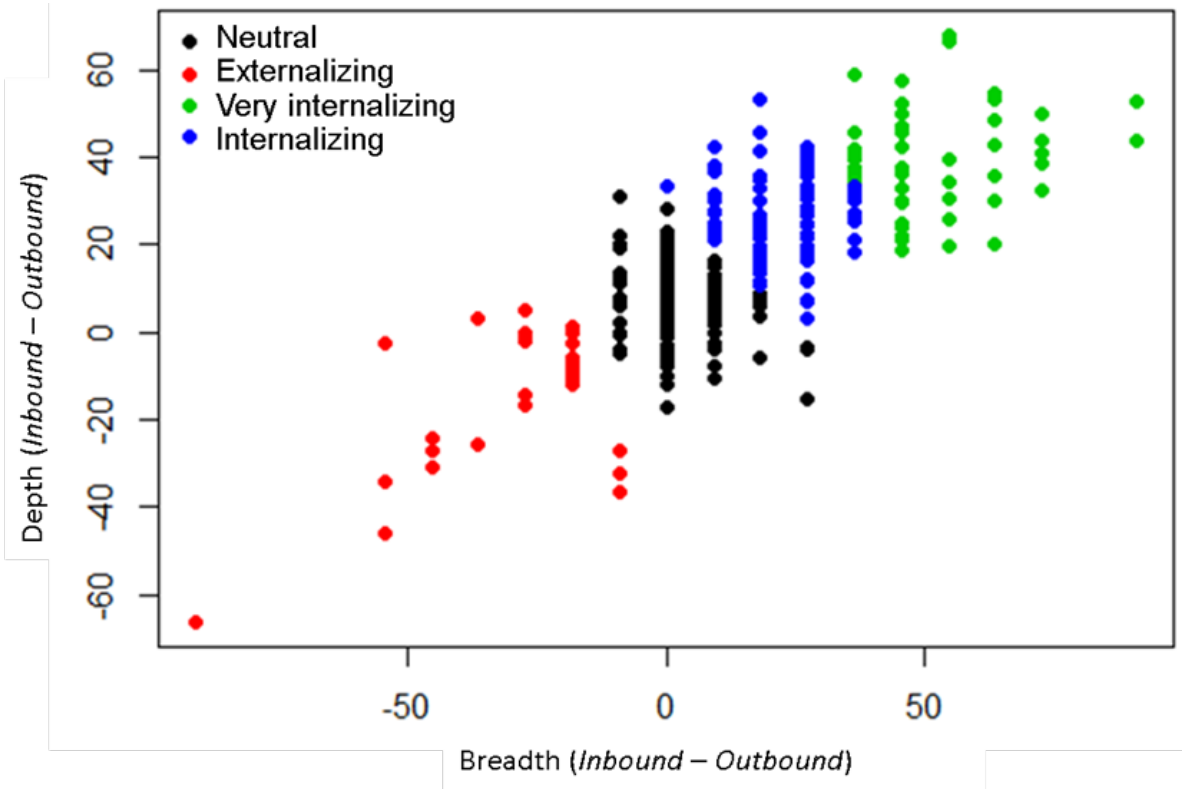

Figure 2. Non-hierarchical clustering (k-means).

Source: Research data (2018).

As seen on the collected data, firms have more inbound than outbound practices, that is, the balance is likely positive. The inbound flow may be characterized as the knowledge that flows from the external environment into the KIBS firm, which may occur through licensing-in (for example, computer software) or even crowdsourcing actions to solve some specific problem in the firm. Licensing-out and transferring intellectual property are still not common, even in intensive knowledge sectors which can more easily codify such knowledge and, consequently, sell it.

Table 3 shows that externalizing firms are those that have a negative balance in the inboundoutbound relation, that is, their outbound flows are bigger than the inbound flow, both in terms of breadth $(-29.47)$ and depth $(-15.64)$. Neutral firms are those in which the flow balance is close to 0 (although they have a slight positive balance).

Firms labelled as "internalizing" in this study have an inbound flow bigger than outbound flow. Meanwhile, in those firms labelled "very internalizing", the difference between inbound and outbound knowledge is large.

Table 3

Clustering Results - K-means method with 4 centroids

\begin{tabular}{|c|c|c|c|c|}
\hline & Externalizing & Neutral & Internalizing & Very Internalizing \\
\hline Breadth Centroid (Inb-Out) & -29.47 & 2.23 & 22.07 & 52.00 \\
\hline Depth Centroid $(\operatorname{In} b-O u t)$ & -15.64 & 7.36 & 26.06 & 38.96 \\
\hline Number of firms & 29 & 163 & 103 & 50 \\
\hline Formal Appropriation & 2.80 & $3.25^{(1)}$ & 3.19 & $2.44^{(1)}$ \\
\hline Informal Appropriation & $4.93^{(1)}$ & $5.00^{(2)}$ & 4.85 & $4.20^{(1,2)}$ \\
\hline Selective Revealing & 3.16 & 3.87 & 3.33 & 3.12 \\
\hline Innovation performance & 5.01 & 5.10 & 5.20 & 4.72 \\
\hline
\end{tabular}

Note: ${ }^{(\mathrm{n})}$ Significant mean differences for $\mathrm{p}$-value $<0.05$ (Nemenyi Test)

Source: Research data (2018). 
BBR

18

The results in Table 3 show that KIBS firms that are said to be neutral (small difference between inbound and outbound flows) used formal and informal appropriation (in boldface) the most; in addition, they adopt the selective revealing strategy more intensely whereas firms said to be "internalizing" have the greatest innovation performance of all four clusters, although there are no significant differences.

The Nemenyi mean test was used to verify whether there are significant mean differences (p-value $<0.05$ ) across the several clusters. To facilitate viewing which pairs present significant mean differences, we inserted superscript numbers. The same superscript number means there is a significant difference between the two means. For example, there is a significant difference of informal appropriation between the "externalizing" firms cluster $\left(4.93^{(1)}\right)$ and the "very internalizing" firms $\left(4.20^{(1)}\right)$.

The internalization flow balance logic will not always mean more revenue to the firm since the outbound flow may represent licensing out and copyright, as well as revealing knowledge that may represent future innovation cooperation.

Lichtenthaler and Lichtenthaler (2009) name the capacity of generating revenue through outbound knowledge flow as "desorptive capacity", that is, the capacity of identifying external opportunities for knowledge transfer, inside-out, based on the analysis of external actors' needs. Although the outbound process may generate revenue through developing innovation internally (Huizingh, 2011), it seems that desorptive practices are still not common in Brazil and that desorptive capacity needs to be better developed.

The outbound flow can also be improved through activities to promote the KIBS technologies, such as advertising in business newspapers, academic texts, and participation in conferences and meetings in associations. This type of effort may be very valid in KIBS firms that need to show their knowledge portfolio to other external actors. These actions make way for revenue through outbound flows and may also mean finding new business clients.

In case of a greater positive inbound-outbound balance, the surveyed sector is likely to suffer less from problems concerning the Not Invented Here syndrome (NIH) (Lichtenthaler \& Ernst, 2006), in which the staff and, consequently, the firm's organizational culture have a negative attitude towards the knowledge produced outside the firm.

On the other hand, buy-in may be overvalued since "very internalizing" firms have the least innovation performance among all four surveyed groups. In this case, overvalued external knowledge is not becoming innovation performance.

A greater inbound flow may also represent a trend of outsourcing innovative activities, although acquiring external knowledge does not, by itself, guarantee a better innovation performance since it will depend on the firm's absorptive capacity (Zobel, 2017). Studies such as that by Fiegenbaum, Ihrig, \& Torkkeli (2014) evidenced that the emphasis on the outbound flow are less lucrative than inbound flows, while the work of Ahn et al. (2016) found the opposite, that is, that outbound flow has a greater impact on financial performance. 


\section{CONCLUSIONS}

Exploring the relationships of appropriation, openness, selective revealing, and innovation performance contributes to amplify the theoretical lens on the influence of specific appropriation strategies (formal and informal) on openness, as well as the relationship of the openness dimensions in terms of flow (outbound, inbound and coupled), breadth and depth on innovation performance.

The open innovation strategy may be considered a firm's internal decision, however, it may be strongly influenced by the systemic innovation context that considers, simultaneously, firms, public institutions, funding agencies, research labs, and universities in concatenation to generate and disseminate innovation.

Our results also contribute to provide insights on the reasons for the predominance of inbound knowledge flow over outbound and coupled flows (also found in works such as that of Huinzigh, 2011). Greater openness may be due to the demands that emerge throughout the innovation process. When a firm detects, a priori, opportunities to complement its own knowledge, it will probably try to set out cooperation (coupled) practices that encompass long-term relationships.

Inbound flows emerge in more advanced phases in project development with the aim to complement some specific knowledge that the firm could not achieve during development, that is, such relations may mean a reactive attitude to problem solving, while cooperation would be more associated with a long-term strategy, which typically encompasses knowledge trading, reciprocity and relationships of trust.

Our findings (more dominance of inbound flows) are in line with other international studies (OECD countries) (Chesbrough \& Crowther, 2006; Cheng \& Huizingh, 2014; Huinzigh, 2011; West \& Bogers, 2014) and they lead to the following understanding: in Brazil, outbound flows (which may occur in cooperative practices or through licensing out or revealing) make managers reticent because they are more concerned with spillovers than with the gains that the outbound flows may generate.

Our results also showed that the KIBS firms whose inbound and outbound flows differ slightly (neutral) eventually use appropriation mechanisms (both formal and informal) to a greater extent, and they adopt the selective revealing strategy more intensely. The positive balance in internalization presented a non-significant innovation performance across the several groups.

This study also represents advances for the Brazilian context due to the specificities of the innovation system and knowledge appropriation. Most research that address this theme is conducted in member countries of the Organisation for Economic Co-operation and Development (OECD), mainly on the European continent. In such countries, the concatenation of firms with external actors, mainly entities that foster innovation, occurs differently due to their own forms of articulation and due to the different legal context, which requires changes in the innovation strategies.

In the national context, a series of themes associated with open innovation would contribute to understanding the specificities of Brazilian firms, in that the country's moral and educational environment are different from that of OECD countries, which concentrate the greatest part of the researches on open innovation. Therefore, we recommend that more studies be conducted to help fill the gaps of understanding the relations between open innovation and dynamic capabilities, cognitive distances, reciprocity and complementarity, for example. 


\section{REFERENCES}

Ahn, J. M., Minshall, T., \& Mortara, L. (2015). Open innovation: a new classification and its impact on firm performance in innovative SMEs. Journal of Innovation Management, 3(2), p33-54.

Alexy, O., George, G., \& Salter, A. J. (2013). Cui bono? The selective revealing of knowledge and its implications for innovative activity. Academy of Management Review, 38(2), 270-291.

Aloini, D., Lazzarotti, V., Manzini, R., \& Pellegrini, L. (2017). IP, openness, and innovation performance: an empirical study. Management Decision, 55(6), 1307-1327.

Arora, A., Athreye, S., \& Huang, C. (2016). The paradox of openness revisited: Collaborative innovation and patenting by UK innovators. Research Policy, 45(7), 1352-1361.

Baldwin, C. Y., \& Henkel, J. (2015). Modularity and intellectual property protection. Strategic Management Journal, 36(11), 1637-1655.

Barge-Gil, A. (2010). Open, semi-open and closed innovators: towards an explanation of degree of openness. Industry and Innovation, 17(6), 577-607.

Bengtsson, L., Lakemond, N., Lazzarotti, V., Manzini, R., Pellegrini, L., \& Tell, F. (2015). Open to a select few? Matching partners and knowledge content for open innovation performance. Creativity and innovation management, 24(1), 72-86.

Brunswicker, S.; Van de Vrande, V. (2017). Explorando a inovação aberta em pequenas e médias empresas. In: Chesbrough, H.; Vanhaverbeke, W.; West, J. Novas fronteiras em inovação aberta (p. 27-54). São Paulo: Blucher.

Cassiman, B., \& Valentini, G. (2016). Open innovation: are inbound and outbound knowledge flows really complementary?. Strategic Management Journal, 37(6), 1034-1046.

Cheng, C. C., \& Huizingh, E. K. (2014). When is open innovation beneficial? The role of strategic orientation. Journal of product innovation management, 31(6), 1235-1253.

Chesbrough, H. (2006). Open business models: How to thrive in the new innovation landscape. Boston: Harvard Business School Press.

Chesbrough, H. W. (2003). Open Innovation: the new imperative for creating and profiting from technology. Boston: Harvard Business School Press.

Chesbrough, H., \& Crowther, A. K. (2006). Beyond high tech: early adopters of open innovation in other industries. R\&D Management, 36(3), 229-236.

Chesbrough, H., Ghafele, R. (2014). Inovação aberta e propriedade intelectual: os dois lados da perspectiva do mercado. In: Chesbrough H.; Vanhaverbeke, W.; West, W. (Orgs.). Novas fronteiras em inovação aberta (p. 225-240). Porto Alegre: Bookman.

Cohen, W. M., \& Levinthal, D. A. (1990). Absorptive capacity: A new perspective on learning and innovation. Administrative Science Quarterly, 35(1), 128-152.

Corrocher, N., Cusmano, L., \& Morrison, A. (2009). Modes of innovation in knowledge-intensive business services evidence from Lombardy. Journal of Evolutionary Economics, 19(2), 173-196.

Cui, T., Ye, H. J., Teo, H. H., \& Li, J. (2015). Information technology and open innovation: A strategic alignment perspective. Information \& Management, 52(3), 348-358.

D’Ambrosio, A., Gabriele, R., Schiavone, F., \& Villasalero, M. (2017). The role of openness in explaining innovation performance in a regional context. The Journal of Technology Transfer, 42(2), 389-408. 
D’Ambrosio, A., Gabriele, R., Schiavone, F., \& Villasalero, M. (2017). The role of openness in explaining innovation performance in a regional context. The Journal of Technology Transfer, 42(2), 389-408.

Dahlander, L., \& Gann, D. M. (2010). How open is innovation?. Research Policy, 39(6), 699-709.

Djellal, F., Gallouj, F., \& Miles, I. (2013). Two decades of research on innovation in services: Which place for public services?. Structural change and economic dynamics, 27, 98-117.

Doloreux, D., \& Shearmur, R. (2013). Innovation strategies: are knowledge-intensive business services just another source of information?. Industry and innovation, 20(8), 719-738.

Drechsler, W., \& Natter, M. (2012). Understanding a firm's openness decisions in innovation. Journal of Business Research, 65(3), 438-445.

Enkel, E., Gassmann, O., \& Chesbrough, H. (2009). Open R\&D and open innovation: exploring the phenomenon. R\&D Management, 39(4), 311-316.

Fiegenbaum, I., Ihrig, M., \& Torkkeli, M. (2014). Investigating open innovation strategies: a simulation study. International Journal of Technology Management 23, 66(2-3), 183-211.

Freel, M., \& Robson, P. J. (2017). Appropriation strategies and open innovation in SMEs. International Small Business Journal, 35(5), 578-596.

Gallouj, F. (2007). Economia da inovação: um balanço dos debates recentes. In: Bernardes, R; Andreassi, T. (orgs.). Inovação em serviços intensivos em conhecimento. São Paulo: Saraiva

Gassmann, O., \& Enkel, E. (2004). Towards a theory of open innovation: three core process archetypes. Proceedings of the R\&D Management Conference, Sesimbra.

Greco, M., Grimaldi, M., \& Cricelli, L. (2016). An analysis of the open innovation effect on firm performance. European Management Journal, 34(5), 501-516.

Hair, J. F., Black, W. C., Babin, B. J., Anderson, R. E., \& Tatham, R. L. (2009). Análise multivariada de dados. Porto Alegre: Bookman.

Hall, B., Helmers, C., Rogers, M., \& Sena, V. (2014). The choice between formal and informal intellectual property: a review. Journal of Economic Literature, 52(2), 375-423.

Henkel, J. (2006). Selective revealing in open innovation processes: The case of embedded Linux. Research Policy, 35(7), 953-969.

Henkel, J., Schöberl, S., \& Alexy, O. (2014). The emergence of openness: How and why firms adopt selective revealing in open innovation. Research Policy, 43(5), 879-890.

Huizingh, E. K. (2011). Open innovation: State of the art and future perspectives. Technovation, 31(1), 2-9.

Hurmelinna-Laukkanen, P., Sainio, L. M., \& Jauhiainen, T. (2008). Appropriability regime for radical and incremental innovations. R\&D Management, 38(3), 278-289.

Idrissia, M., Amaraa, N., \& Landrya, R. (2012). SMEs' degree of openness: the case of manufacturing industries. Journal of Technology Management \& Innovation, 7(1), 186-210.

Katila, R., \& Ahuja, G. (2002). Something old, something new: A longitudinal study of search behavior and new product introduction. Academy of Management Journal, 45(6), 1183-1194.

Laihonen, H., Aloini, D., Pellegrini, L., Lazzarotti, V., \& Manzini, R. (2015). Technological strategy, open innovation and innovation performance: evidences on the basis of a structural-equationmodel approach. Measuring Business Excellence, 9(3), 22-41. 
BBR

18

Laihonen, H., Aloini, D., Pellegrini, L., Lazzarotti, V., \& Manzini, R. (2015). Technological strategy, open innovation and innovation performance: evidences on the basis of a structural-equationmodel approach. Measuring Business Excellence.

Laursen, K., \& Salter, A. (2006). Open for innovation: the role of openness in explaining innovation performance among UK manufacturing firms. Strategic Management Journal, 27(2), 131-150.

Laursen, K., \& Salter, A. J. (2014). The paradox of openness: Appropriability, external search and collaboration. Research policy, 43(5), 867-878.

Lazzarotti, V., Bengtsson, L., Manzini, R., Pellegrini, L., \& Rippa, P. (2017). Openness and innovation performance: an empirical analysis of openness determinants and performance mediators. European Journal of Innovation Management, 20(3), 463-492.

Leiponen, A., \& Helfat, C. E. (2010). Innovation objectives, knowledge sources, and the benefits of breadth. Strategic Management Journal, 31(2), 224-236.

Lichtenthaler, U., \& Ernst, H. (2006). Attitudes to externally organising knowledge management tasks: a review, reconsideration and extension of the NIH syndrome. R\&D Management, 36(4), 367-386.

Love, J. H., Roper, S., \& Bryson, J. R. (2011). Openness, knowledge, innovation and growth in UK business services. Research Policy, 40(10), 1438-1452.

Martini, A., Aloini, D., \& Neirotti, P. (2012). Degree of Openness and Performance in the Search for Innovation. International Journal of Engineering Business Management, 4(Godište 2012), 4-37.

Mina, A., Bascavusoglu-Moreau, E., \& Hughes, A. (2014). Open service innovation and the firm's search for external knowledge. Research Policy, 43(5), 853-866.

Mina, A., Bascavusoglu-Moreau, E., \& Hughes, A. (2014). Open service innovation and the firm's search for external knowledge. Research Policy, 43(5), 853-866.

Miozzo, M., Desyllas, P., Lee, H. F., \& Miles, I. (2016). Innovation collaboration and appropriability by knowledge-intensive business services firms. Research Policy, 45(7), 1337-1351.

Natalicchio, A., Ardito, L., Savino, T., \& Albino, V. (2017). Managing knowledge assets for open innovation: a systematic literature review. Journal of Knowledge Management, 21(6), 1362-1383.

Nooteboom, B.(1999). Inter firm alliances: Analysis and Design. New York: Routledge.

Rodriguez, M. (2008). Are KIBS more than intermediate inputs? An examination into their R\&D diffuser role in Europe. Georgia Institute of Technology.

Rodriguez, M., Doloreux, D., \& Shearmur, R. (2016). Innovation strategies, innovator types and openness: a study of KIBS firms in Spain. Service Business, 10(3), 629-649.

Shi, X., Wu, Y., \& Zhao, D. (2014). Knowledge intensive business services and their impact on innovation in China. Service Business, 8(4), 479-498.

Spithoven, A., \& Teirlinck, P. (2015). Internal capabilities, network resources and appropriation mechanisms as determinants of R\&D outsourcing. Research Policy, 44(3), 711-725.

Strambach, S. (2008). Knowledge-Intensive Business Services (KIBS) as drivers of multilevel knowledge dynamics. International journal of services technology and management, 10(2-4), 152-174.

Teirlinck, P., \& Spithoven, A. (2013). Research collaboration and R\&D outsourcing: Different R\&D personnel requirements in SMEs. Technovation, 33(4-5), 142-153. 
Uduma, I. A., Wali, A. F., \& Wright, L. T. (2015). A quantitative study on the influence of breadth of open innovation on SMEs product-service performance: The moderating effect of type of innovation. Cogent Business \& Management, 2(1), 1120421.

Van de Vrande, V., Vanhaverbeke, W., \& Duysters, G. (2011). Technology in-sourcing and the creation of pioneering technologies. Journal of Product Innovation Management, 28(6), 974-987.

West, J., \& Bogers, M. (2014). Leveraging external sources of innovation: a review of research on open innovation. Journal of Product Innovation Management, 31(4), 814-831.

Zobel, A. K. (2017). Benefiting from open innovation: A multidimensional model of absorptive capacity. Journal of Product Innovation Management, 34(3), 269-288.

Zobel, A. K., Lokshin, B., \& Hagedoorn, J. (2017). Formal and informal appropriation mechanisms: The role of openness and innovativeness. Technovation, 59, 44-54.

\section{CONFLICTS OF INTEREST}

The authors declares that there is no conflict of interest regarding the publication of this article.

\section{AUTHOR'S CONTRIBUTION}

Author 1 - Defining The Research Problem; Review of Literature; Methodological Procedures; Data collection; Data Analysis and Interpretation; Writing Text; Reviewing Text.

Author 2 - Defining The Research Problem; Data Analysis and Interpretation; Writing Text; Reviewing Text. 


\begin{tabular}{llll}
\hline Construct & Item & Description & References \\
\hline & AB1 & Business clients & \\
& AB2 & Individual clients or users & Laursen; Salter, \\
& AB3 & Competitors & (2006, 2014); Cui et \\
& AB4 & Suppliers & al., (2015); Uduma, \\
& AB5 & Consulting firms & Wali and Wright, \\
Openness & AB6 & Business laboratories or private research institutes & (2015); Laihonen et \\
& AB7 & Universities or other higher education institutions & Grimaldi \& Cricelli \\
& AB8 & Public sector and public research institutes & (2016); Freel \& \\
& AB9 & Technical assistance and professional training centers & Robson (2017) \\
& AB10 & Testing and certification institutions & \\
AB11 & Business associations & \\
\hline
\end{tabular}

AB11 Business associations

AF1

AF2

AF3 (Formal and Informal)

\section{$\mathrm{AF}$}

AI1
Appropriation
Selective

Revealing
AI2

$\mathrm{AI} 3$

AI4

AI5

RS1

RS3

\section{innovations.}

Influencing other organizations to converge to our

RS4 technological path so as to make others get iReducing development costs of new products and services.

RS5 Outlining practices adopted by professionals and trade associations connected to our business.

Using crowdsourcing (obtaining ideas through virtual

RS6 communities) for other organizations or individuals to solve our problems.

DI1 Reducing development costs of new products and services.

DI2 Reducing products and services trade time.

Innovation Performance
DI3

Introducing new or significantly improved products and services.

DI4 Introducing new or significantly improved processes.

DI5 Opening new markets to your products and services.
Cheng \& Huizingh (2014); Aloini et al. (2015); Baldwin \& Henkel (2015); Spithoven, Teirlinck (2015); Laihonen et al. (2015); Zobel, Lokshin \& Hagedoorn (2017);

Freel and Robson (2017);

Henkel (2006); Alexy, George \& Salter (2013); Henkel, Scheorge \& Alexy (2014).

Laursen and Salter (2006); Laihonen et al. (2015); Cui et al. (2015); Arora, Athreye \& Huang (2016);

D’Ambrosio et al. (2017) 
APPENDIX B - FACTOR CHARGES - MATRIX COMPONENT

\begin{tabular}{|c|c|c|c|c|c|}
\hline Indicator & Openness & $\begin{array}{c}\text { Formal } \\
\text { Appropriation }\end{array}$ & $\begin{array}{c}\text { Informal } \\
\text { Appropriation }\end{array}$ & $\begin{array}{l}\text { Selective } \\
\text { Revealing }\end{array}$ & $\begin{array}{l}\text { Innovation } \\
\text { Performance }\end{array}$ \\
\hline ABEINB & 0.893 & & & & \\
\hline ABEOUT & 0.899 & & & & \\
\hline $\mathrm{ABECOU}$ & 0.926 & & & & \\
\hline $\mathrm{AF} 1$ & & 0.816 & & & \\
\hline AF2 & & 0.747 & & & \\
\hline AF3 & & 0.744 & & & \\
\hline AF4 & & 0.701 & & & \\
\hline AI1 & & & 0.783 & & \\
\hline AI 2 & & & 0.691 & & \\
\hline $\mathrm{AI} 3$ & & & 0.674 & & \\
\hline AI 4 & & & 0.794 & & \\
\hline $\mathrm{AI} 5$ & & & 0.768 & & \\
\hline RS1 & & & & 0.789 & \\
\hline RS2 & & & & 0.764 & \\
\hline RS4 & & & & 0.861 & \\
\hline RS5 & & & & 0.807 & \\
\hline DI3 & & & & & 0.848 \\
\hline DI4 & & & & & 0.806 \\
\hline DI2 & & & & & 0.790 \\
\hline DI5 & & & & & 0.742 \\
\hline DI1 & & & & & 0.736 \\
\hline
\end{tabular}

Source: Primary data. 